Alix Heiniger and Thomas David

\title{
Mobility and Social Control: French Immigration in Geneva during the Belle Époque
}

\begin{abstract}
Following recent research that invites historians to take into account immigrant communities to understand migration control policies before the First World War, this article examines the activities of French philanthropists in Geneva during the Belle Époque. It aims to show how these actors belonging to the French elite of Geneva drew the line between poor people who could stay in the canton and the ones who had to leave, and how they exercised social control within the community. The authorities of Geneva, in particular the police, expelled people with no means of support. The article thus argues that social rights were at the core of migration policies. In so doing, it examines three different groups of immigrants: the French elite, who took care of the community, the people they supported by their philanthropic activities and the people who were expelled from Geneva by the police.
\end{abstract}

\footnotetext{
With the Chamber of Commerce, which devotes itself especially to the study and defence of commercial and industrial interests, with the groupement des Sociétés de bienfaisance [Association of Charities], which provides assistance to those whom fate has disadvantaged compared to their happier compatriots, the Cercle français [French Circle] constitutes the firm tripod which the Consulate-General needs to accomplish its mission [...]. ${ }^{1}$
}

In a commemorative brochure on the Cercle français, a society dedicated to providing a meeting place for French residents of Geneva, its committee stressed the division of roles between French organisations. It put forward a tripod which included a venue for social gatherings (the Cercle français), an association to defend French economic interests in Geneva (the Chamber of Commerce) and the promotion of philanthropic activities (the Association of Charities). In evoking the latter, the author stressed the complex character of migration, which covered a diversity of social situations, and the involvement of more affluent French citizens in helping their compatriots whose financial situation was less fortunate. This observation invites us to grasp the phenomenon of migration in all its complexity by bringing the category of national affiliation together with other factors in order to understand what transnational mobility really meant in the course of the lives of individuals and the manner in which it has contributed to shaping modern

1 Cercle Français de Genève. Geneva 1939, 15. 
society. On a conceptual level, this aim calls for a merger of the two approaches which have dominated the history of migration: on the one hand, transnational experiences of immigrants (focusing on the integration of migrants into their new environment and their connections to their country of origin) and, on the other, approaches focusing on migration policies aimed at immigrants. ${ }^{2}$

This article intends to navigate between these two poles in order to demonstrate the functioning of the mechanisms of inclusion and exclusion that permit people to remain in the host society or that would instead disqualify them, obliging them to leave. The migrants themselves were present both among the actors who established and reproduced these mechanisms and among those affected by the policies. Foreign communities constituted complex worlds characterised by strong internal social differences. ${ }^{3}$ At their core, the philanthropic organisations allowed the most vulnerable to maintain a standard of living that kept them safe from expulsion. They were fully involved in regulatory policies affecting migration, notably through drawing (or reinforcing) the boundaries between migrants who could remain and those who had to leave. They exercised social control over their most disadvantaged compatriots while, at the same time, providing the assistance necessary to their survival or their integration into the host society. ${ }^{4}$ Furthermore, the study of charities benefiting foreigners makes it possible to highlight different kinds of transnational life courses that otherwise would remain hidden, those of the people supported by the charities and those of their leaders. By taking into account different kinds of social groups involved in the migration process, we can tackle the idea of "motility", related to opportunity structures, capacities and agency of individuals. ${ }^{5}$ By doing so, we aim to focus on the cultural and social aspects of boundary-crossings, as the requirement for integration differed depending on the social group the migrants belonged to. Moreover, charities and other French organisations in Geneva linked their supporters to both French and Genevan contexts, as they were keen on promoting French interests in the city and developing relationships with their Genevan counterparts. The concept of

2 Paul-André Rosental: Historiographical Challenges of Emigration Policy, in: Annuaire suisse d'histoire économique et sociale. La Suisse ailleurs. Les Suisses de l'étranger - Les Suisses à l'étranger 29 (2015), 39-52.

3 See, for example, Nancy L. Green: The Other Americans in Paris. Businessmen, Countesses, Wayward Youth, 1880-1941. Chicago 2014.

4 Nancy Green shows how Jewish charitable organisations in Paris exercised social control over the community, favouring the integration of newcomers but at the same time restricting their freedom. See Nancy L. Green: To Give and to Receive. Philanthropy and Collective Responsibility among Jews in Paris, in: Peter Mandler (ed.): The Use of Charity. The Poor on Relief in the Nineteenth-Century Metropolis. Philadelphia 1990, 197-226.

5 See the introduction to this volume. 
"rooted cosmopolitanism" presented in the introduction to this volume is eminently suited to describing these people connected both to their country of origin and to their host society.

In a more global context, French charities in Geneva took part in a process that went far beyond Switzerland. Their activities occurred at a time when most European states had measures on their statute books enabling them to expel foreigners who failed to provide sufficient guarantees concerning their capacity to provide for their own needs. Such policies were reaffirmed at the turn of the century with the advent of social welfare systems, in which the question of the link between citizenship and social rights was omnipresent. ${ }^{6}$ Historiography has shown that even when systems governing the circulation of individuals before the First World War appeared to reflect a liberal policy, the living conditions and rights of foreigners were much less favourable than today, and expulsion was a flexible tool for managing migration and maintaining public order. ${ }^{7}$

Geneva is ideal for studying these phenomena since, at the turn of the century, it was home to a very high proportion of foreigners. Amongst these, the French constituted the largest population and had created several charitable organisations for mutual aid, led by French expatriates who collaborated with local private and public institutions. In the first section, we will analyse the specific situation of Geneva, which explains the strong presence of foreigners on its territory. Then, we will focus on the elite of the "French colony" - a term used by the members of the elite themselves - and how its members intended to represent the community and help the most disadvantaged. In the third section, the elite are the subjects of a typology which seeks to understand how social control operated. The final section deals with those who were excluded, who were not integrated into Genevan society and subject to expulsion. Ultimately, our objective is to show that in examining the social hierarchies within the French community, it is possible to reestablish more precisely the complexity of migration phenomena and to comprehend the

6 For France, see Paul-André Rosental: Migrations, souveraineté, droits sociaux. Protéger et expulser les étrangers en Europe du XIXe siècle à nos jours, in: Annales. Histoire, Sciences Sociales 2 (2011), 335-373. For Switzerland, see Silvia Arlettaz and Gérald Arlettaz: L'État social national et le problème de l'intégration des étrangers 1890-1925, in: Études et Sources. L'histoire des assurances sociales 31 (2006), 191-217.

7 Rosental, Migrations, 335-373; and David Feldman: Was the Nineteenth Century a Golden Age for Immigrants? The Changing Articulation of National, Local and Voluntary Controls, in: Andreas Fahrmeir, Olivier Faron and Patrick Weil (eds.): Migration Control in the North Atlantic World. The Evolution of State Practices in Europe and the United States from the French Revolution to the Inter-War Period. New York 2005, 167-177; and Frank Caestecker: The Transformation of Nineteenth-Century West European Expulsion Policy, 1880-1914, in: ibid., 120-137, esp. 121. 
process by which foreigners who would be excluded from the territory and those who would be integrated into the host society were selected.

Our analysis is based on both a rich corpus of archives of French charitable organisations active in Geneva at the turn of the century, and the systematic and detailed analysis of the 1,121 files created following the expulsion of individuals from the canton of Geneva in 1902. Combining these two types of data is an original aspect of our approach. It aims to gain insight into the line drawn between individuals integrated into Genevan society and those who were excluded from it, while also showing that philanthropic organisations participated in selecting individuals and, subsequently, in the migration policies devised by public and private institutions. Such an approach brings together "structure" and "agency", showing under what conditions it was possible to remain in Geneva or, on the contrary, why some should leave. Furthermore, those sources reveal biographies of mobility, showing how, when and possibly why migration was considered by individuals to be the right (or the only) choice in their lives.

\section{Foreigners in Switzerland and in Geneva: the Construction of a "Problem"}

The turn of the century witnessed an intensification of migratory movements across the globe, due to economic development and progress in communication. This circulation of individuals was particularly striking in Switzerland, where the proportion of foreigners in the resident population was much greater than in other European countries.

Table 1: Proportion of Foreigners in the Population of European Countries (in \%) ${ }^{8}$

\begin{tabular}{llr}
\hline & $\mathbf{1 8 8 0}$ & $\mathbf{1 9 1 0}$ \\
\hline Switzerland & 7.4 & 14.7 \\
France & 2.7 & 2.9 \\
Germany & 0.6 & 1.9 \\
United Kingdom & 0.8 & 2.1 \\
Belgium & 2.6 & 3.4 \\
\hline
\end{tabular}

8 Source: Paul Bairoch: La Suisse dans le contexte international aux XIXe et XXe siècles, in: id. and Martin Körner (eds.): La Suisse dans l'économie mondiale - Die Schweiz in der Weltwirtschaft. Zurich 1990, 103-140, esp. 119. 
These differences, notably in comparison to France, were probably due in part to the application of the principles jus sanguinis or jus solis, the latter allowing for an almost automatic assimilation from the second generation on. Nonetheless, at this time, most states of the German Empire also applied jus sanguinis, without, however, having as large a proportion of foreigners as in Switzerland.

Yet significant disparities also existed within Switzerland. Certain cantons, such as Appenzell Innerrhoden, with only 2.4 per cent aliens, had smaller proportions of foreigners while others had more than 15 per cent. Geneva came out on top with the most foreigners (39.7 per cent), followed by Basel (38.1 per cent) and Ticino (22.0 per cent). ${ }^{9}$ These three cantons all share more borders with a third country than with the Confederation. In this respect, Geneva is an extreme case, very well described by the statistician of the canton, Emmanuel Kuhne: "For a long time, the canton of Geneva, almost surrounded by France, was the natural centre of emigration of the Savoy and Gex zones. Being the economic capital of a region of which it is not the political capital explains our city's unusual situation [...]." 10

As Table 2 reveals, for 60 years, the French constituted the most significant portion of Geneva's foreign population. Like others, the statistician associated this situation with a problem: "The danger for Genevan nationality is obvious and it has long worried the far-sighted among us."11 For him, the naturalisation of those born in the territory constituted a solution. Nevertheless, there were still "an

Table 2: Foreign Population in the Canton of Geneva (1860-1920) ${ }^{12}$

\begin{tabular}{lllc}
\hline & $\begin{array}{l}\text { Foreigners } \\
\text { (in \%) }\end{array}$ & $\begin{array}{l}\text { French } \\
\text { (in \%) }\end{array}$ & $\begin{array}{l}\text { Total Population } \\
\text { (in absolute numbers) }\end{array}$ \\
\hline 1860 & 34.7 & 29.3 & 82,876 \\
1870 & 38.2 & 31.5 & 93,239 \\
1880 & 37.3 & 29.5 & 101,595 \\
1900 & 38.9 & 25.9 & 132,389 \\
1910 & 41.5 & 21.5 & 165,986 \\
1920 & 30.2 & 15.6 & 171,000 \\
\hline
\end{tabular}

9 Calculations are based on Statistiques historiques de la Suisse. URL: http://www.fsw.uzh.ch/ histstat/main.php (18 May 2015), “population” Tables B 23 and B 44.

10 Emmanuel Kuhne: Les étrangers dans le canton de Genève. Geneva 1898, esp. 3.

11 Ibid.

12 Sources: Genève, in: Dictionnaire historique de la Suisse. URL: http://www.hls-dhs-dss.ch/ textes/f/F7398.php (22 June 2015); Paul Bairoch and Jean-Paul Bovee: Annuaire statistique rétrospectif de Genève. Geneva 1986, esp. 15-16. 
enormous number of residents who enlarge our population without having either our habits or our traditions and who have, thanks to treaties of establishment, the same rights as nationals, except in terms of voting." ${ }^{13}$ Still, the contribution of the foreign population was required for the economic development of the canton since, according to Kuhne's research, Genevans had abandoned certain professions and left them to foreigners: "In the country, the workers, servants and labourers are almost all French and the Genevans tend to form a sort of aristocracy which owns and cultivates the land, but leaves the hard work to others." ${ }^{14}$ Foreigners were overrepresented in less qualified jobs and a great many of them worked as day labourers or domestic servants. In the industrial sector, they represented more than 45 per cent of those in the clothing and grooming industry, and they constituted 50 per cent of those working in construction. They were also active in the development and maintenance of roads. However, they were largely absent from watchmaking, one historic industry of Geneva. ${ }^{15}$

An analysis of residence permit registers from the year 1900, which includes the foreigners who arrived in the canton but not those who were already established, shows that most of the migrants were young adults. The author of this analysis concluded that they were attracted by the economic opportunities of the canton. He formed the hypothesis of a dichotomous structure related to the nature of the migration. On the one hand, migrants settled for the long term and were likely to make a home and start a family in Geneva and, on the other hand, transmigrants (mostly men) intended to work a few months and then leave. ${ }^{16}$ While many French residents of Geneva fit these profiles, others were experiencing wholly different economic and social situations. The study of French philanthropic organisations reveals two other types of social profiles, of people who benefitted from their help and of their considerably more affluent leaders.

13 Kuhne, Les étrangers, 13.

14 Ibid., 10.

15 See Emmanuel Kuhne: Recensement professionnel de 1902. Geneva 1904, esp. 34.

16 Luc Morisseau: Les immigrés à Genève en 1900. Une analyse du registre des permis de séjour étrangers (Master's thesis, University of Geneva, 2008), 24. These seasonal and cross-border migratory shifts were not unique to the canton of Geneva. In France, for example, the same type of circulation existed in the regions of the North and of the Midi, where seasonal workers did agricultural labour starting in the springtime and then left after the harvest. Furthermore, the construction sector also employed a foreign labour force which compensated for a lack of local workers. See Gérard Noiriel: Immigration, antisémitisme et racisme en France (XIXe-XXe siècle. Discours publics, humiliations privées). Paris 2007, esp. 136-137. On the question of internal immigration in the rural environment, see Claire Lemercier and Paul-André Rosental: Pays ruraux et découpage de l'espace. Les réseaux migratoires dans la région lilloise au milieu du XIXe siècle, in: Population 4-5 (2000), 691-725. 


\section{An Elite Which Looks after the "Colony"}

The French colony in Geneva ran four philanthropic organisations, in addition to another dozen which played a less central role in the organisation and distribution of assistance. ${ }^{17}$ The oldest of the four charitable organisations was the Société française mutuelle et philanthropique (SFMP - The French Mutual and Philanthropic Society), founded in 1842. In 1900, it concluded an agreement with its junior counterpart, created in 1870, the Société Française Philanthropique (SFP the French Philanthropic Society), to rationalise assistance to French citizens and avoid "duplication or worse." Following this accord, the consulate decided to delegate to the SFP the help it was giving to "French destitutes" and provided it with a subsidy, thereby making it the central body within the colony for the distribution of assistance. ${ }^{18}$ Two other charitable organisations were founded later to assist specific groups: children and the elderly. In 1899, a review committee chaired by the consul general of France created the Euvre de l'Enfance française abandonnée (The French Charity for Abandoned Children). ${ }^{19}$ The last of the four to be established, the Euvre des Vieillards et Incurables Français (The French Charity for the Elderly and Incurably), was created in 1903 and ran the Asile de Feuillasse, a home for the elderly. ${ }^{20}$ The latter two included a member of three other societies within their respective committees. From 1904 on, an administrator managed the SFP and the two more recent charitable organisations devoted to elderly and to children, which also shared their offices. He was responsible for the distribution of assistance and investigations into the situation of those requesting help. ${ }^{21}$ Thus, at the start of the century, the French philanthropic milieu's

17 They were also not as close to the consulate. In particular, we have identified the Cercle ouvrier, the Cercle savoisien, the Union savoisienne, the Société savoisienne, the Vétérans des armées de terre et de mer, the Anciens combattants de 1870, the Union des anciens militaires, the Union musicale française, the Vallées du Mont Blanc, the Électeurs de la Haute-Savoie, the Souvenir français, the Jeune République and the Mont Blanc.

18 Committee Report for the Year 1900, Société Française Philanthropique de Genève (Private Archives). See also Irma Gadient: Fürsorge(-kriterien) für Französinnen und Franzosen. Französische philanthropische Vereine in Genf und die Zusammenarbeit mit lokalen wohltätigen Institutionen um 1900, in: Österreichische Zeitschrift für Geschichtswissenschaften 26, no. 3 (2015), forthcoming.

19 Journal Français, 13 Dec. 1907. The committee was composed of nine representatives from the French Chamber of Commerce of Geneva, six from the Cercle français, six from the SFP, two from the SFMP and one from each of the bodies mentioned in footnote 17.

20 Report of the Committee on Operations and the Situation of the Society during the Year 1907, Société de l'EEuvre des Vieillards et Incurables Français de Genève (Private Archives).

21 Gadient, Fürsorge(-kriterien), 11. 
charitable work became more specialised, rationalised and professionalised, a tendency not unique to foreign organisations and which could also be observed in the practice of private Genevan charities. ${ }^{22}$ French philanthropic organisations acted with the support of the French consulate in Geneva. Indeed, in addition to subsidies distributed through its intermediary (the total of which amounted to 3,000 francs ${ }^{23}$ ), the consul participated in charitable organisations as honorary chairman. The SFP appeared as the core of these developments since its members had initiated these projects of rationalisation and of mutualisation. These efforts allowed them to monopolise the resources of French aid and their distribution to disadvantaged members of the community. This situation was not unique to Geneva. In other cities, organisations representing a foreign colony also provided relief in favour of their compatriots. ${ }^{24}$ What seems, however, remarkable in the Genevan case of French relief is how early the system emerged (starting in the middle of the nineteenth century) and the degree of coordination with the French consulary authorities it had reached by the turn of the century. But it is difficult to confirm this hypothesis considering the lack of studies related to other foreign relief organisations.

The representatives of philanthropic organisations were simultaneously involved in other societies connected to the French colony, as well as in Genevan organisations. Alexandre Schwob was a prime example of this multi-positionality. As a member of the committee of the SFP, he played an important role at the heart of the community, being not only behind the establishment of the Cercle français but also acting as chief medical officer to the home for French senior citizens, for which he was awarded the Legion of Honour. In addition, his involvement with patients in his neighbourhood earned him the nickname of "the good Lord of Pâquis". He was also a member of local organisations such as the medical society of Geneva, and presided over the Jewish community of the canton. His wife was no less active, founding and presiding over the Societé des dames françaises de Genève (Society of French Ladies of Geneva). ${ }^{25}$

22 Stéphane Baciocchi et al.: Les mondes de la charité se décrivent eux-mêmes. Une étude des répertoires charitables au XIXe et au début du XXe siècle, in: Revue d'histoire moderne et contemporaine 61, no. 3 (2014), 28-66, esp. 33-37.

232,000 francs from the Ministry of Foreign Affairs and 1,000 francs from the consulate, for receipts totalling 14,730.60 francs. See Report of the Committee for the Year 1904. Société Française Philanthropique de Genève (Private Archives), esp. 5.

24 See, for instance, Nancy Green's recent book: Other Americans, 196-202.

25 Another example (among many) would be Tony Laval, president of the SFP (1900-1902), who was also head of the new Société des tramways in Geneva. See Gadient, Fürsorge(-kriterien), esp. 8. Portrait of A. Schwob in the Journal Français, 11 Aug. 1906. 
Even if these actors were well integrated into Genevan society, they created and facilitated places which perpetuated the idea of a French community in organising events on national holidays and cultivating distinctive national characteristics. The Journal Français, which claimed to be the "voice of French colonies in Switzerland," 26 was part of this dynamic, in publicising eminent figures and events in the life of this community, to which it referred as "the Colony". The principal places for social encounters between these actors were the Cercle français, the French Chamber of Commerce and the philanthropic organisations. Founded in 1896, the Cercle français united the "elite of the Colony" 27 . When asked their occupation, the most commonly named were merchant (27), annuitant (11), landlord (10), physician and director of French firms such as Crédit Lyonnais, Moët et Chandon or Peugeot. The annual membership fee rose to 50 francs, well beyond that of local philanthropic societies, which asked for approximately five francs. The Cercle also admitted Genevans whose social profile was close to that of other members. From 1916 on, the members' list also shows that less than half saw military action, and that those who "fell gloriously on the field of honour for France" were mostly officers. ${ }^{28}$ This reflects two tendencies: On one hand, it indicates that they were somewhat older; on the other hand, in the context of war, publicising the military involvement of members amounts to affirming the contribution of the French citizens established in Geneva to the defence of their homeland. Such demonstrations of patriotism also appeared in other social contexts and environments where the French community made itself known, notably the French Chamber of Commerce and the Journal Français. The Cercle offered a place where members could meet and socialise during the week, much like a club, and at times dinners were sponsored by a member. It served a dual function, which may appear contradictory, but which, in fact, constituted a particular resource: it allowed its members to cultivate national cohesion while also integrating them into local society by creating links with Genevan members.

The French Chamber of Commerce in Geneva, which initiated the Cercle, was established two years earlier and brought together people with similar social profiles (merchants, industrialists or bankers). Aside from being a place for social encounters, the Chamber defended its members' economic interests before Genevan and Swiss authorities, closely monitoring negotiations with regard to the train lines or the volume of French exports to Switzerland. ${ }^{29}$

26 This was the caption inscribed on the front page.

27 Journal Français, 11 Nov. 1910.

28 List of members, as of 1 July 1916, Cercle Français de Genève (Bibliothèque de Genève).

29 Founded in 1894, it had 850 members in 1906. Journal Français, 19 May 1906. 
Thus, the Cercle and the Chamber pursued the triple objective of serving as a place for social encounters for the French elite, cultivating distinctive national characteristics amongst French citizens, and encouraging integration through contacts with the Genevan elite. In addition to these activities, one may add philanthropy, which in some ways constituted the third component of the tripod: sociability, economic promotion and elites' social responsibility. This last aspect was the means to link individuals situated at the extremes of the community's social hierarchy, since the most affluent assumed the responsibility for helping the neediest. The SFP, which occupied a central place in the philanthropic activities of the French community, was directed by a committee composed exclusively of men, whose terms of involvement varied from relatively short periods of two or three years to remarkably long commitments, such as that of the outgoing president in 1900 who served in this position for more than 25 years. These two types of mandates demonstrate the degree to which these officeholders were settled in Geneva: some for the long term, while others for only a short period. While the committee was exclusively male, women also contributed to philanthropic activities, particularly by organising social and cultural fund-raising events.

Membership of the Cercle and the SFP frequently overlapped. ${ }^{30}$ Business and banking were well represented by employees of such companies as Crédit Lyonnais. The proximity of the two societies was further reinforced by the fact that the SFP held its annual assemblies in the salons of the Cercle.${ }^{31}$ Léon Niepce personified the links between the two societies. This French industrialist, born in Isère in 1855 and elected president of the Chamber in 1906, was deeply involved in French charitable organisations. He was active in the Fondation de l'Enfance française abandonnée and in the Asile des vieillards français, over which he presided from 1905 on. In addition, he was on the committee of the SFP. ${ }^{32}$ The latter also cultivated direct links with France, on the one hand by receiving donations from eminent philanthropists, such as Baron de Rothschild or Madame d'Haussonville ${ }^{33}$

30 Unfortunately, these are the only two lists available to us. List of members as of 1 July 1916, Cercle français de Genève (Bibliothèque de Genève); Report of the Committee for the Year 1903. Société Française Philanthropique de Genève (Private Archives).

31 Report of the Committee for the Year 1900. Société Française Philanthropique de Genève (Private Archives).

32 Portrait de Léon Niepce, Journal Français, 9 June 1906.

33 The Baron de Rothschild came from a family of Parisian bankers and philanthropists notable for the establishment of the eponymous hospital. About the Rothschild family, see Rainer Liedtke's contribution in this volume. Madame d'Haussonville is probably the wife of the politician and lawyer Paul-Gabriel d'Haussonville. He was also known for his reform activities and wrote essays about several social issues (prison, child protection and workers' life conditions in Paris). 
and, on the other, by coming to the aid of compatriots in neighbouring French territories during extraordinary events such as at St. Gervais in $1892 .{ }^{34}$ Yet the SFP's activity concentrated primarily on the French population of Geneva. Its actions demonstrated the boundaries of the colony for, in deciding on the granting of aid, it had the power to decide on whether to include or exclude the most disadvantaged. Those excluded, who failed to meet the criteria that allowed foreigners to remain in the canton, were simply expelled from its territory, and then banned from the French community of Geneva.

\section{Vulnerable Populations in the Community: The Beneficiaries of Charitable Organisations}

In principle, the fate of French citizens asking for help in the territory of Geneva was determined by the 1882 Treaty of Establishment between France and Switzerland. ${ }^{35} \mathrm{As}$ with all bilateral texts, it provided for reciprocity in the treatment of the expatriates of the other country. Furthermore, in matters of assistance it rested on the assumption of responsibility for the care of individuals, up to and including the possibility of their safe return, the rest being left to the judgment of the cantons. This task fell back on private organisations who had the responsibility to provide assistance. Yet, at the same time, this also underscored their importance in foreign communities. ${ }^{36}$ This was the situation in Geneva, where the police was responsible for financing the care and repatriation of foreigners without means, and the charitable organisations supported French families in economic difficulties, thus allowing them to stay in the canton. This division of labour between the police and charitable organisations overlaps with the question of inclusion in and exclusion from the French community, since aid from the police contributed to departure from Geneva, and that from charities to staying on.

The assistance practices of French charitable organisations, the SFP, the Euvre des Vieillards and Enfance française abandonnée, are analysed in this article, based on archival holdings common to the three organisations, which

34 The overflowing of a stream destroyed a large part of the bathing establishment and left more than 200 victims. See URL: http://sciences.gloubik.info/spip.php?article1017 (18 May 2015).

35 See Stéphanie Leu: Les petits et les grands arrangements. L'État bilatéral. Une réponse au défi quotidien de l'échange de populations. Une histoire diplomatique de la migration et du droit des migrants entre France et Suisse. Organisation, acteurs et enjeux (inter)nationaux. Milieu XIXe-1939 (Doctoral thesis, Institut d'Études Politiques de Paris and Université de Berne 2012), 12.

36 Ibid., 142. 
contain minutes of meetings, annual reports and accounts for the period between 1886 and 1914. Between 1886 and 1900, the committee of the SFP discussed the allocation of aid in meetings or outside of meetings, and subsequently validated them. Then, from the arrival of the administrator and the establishment of the agreement with the Enfance Française abandonnée and the Euvre des Vieillards français, the decisions no longer appeared in the minutes, probably because they now fell to the administrator. ${ }^{37}$

The SFP came to the assistance of three types of groups: the recipients of regular or occasional assistance; those who went to food distribution which operated twice weekly during the winter; and those whose received vouchers for the Asile de nuit (night shelter) and were repatriated (at least partly) by the SFP.

The first group includes those installed in Geneva who received either regular or occasional support in the form of a pension. They were usually the children of workers, widows with or without children, senior citizens or those with disabilities. The pensions were quite modest, ranging between three and 15 francs a month, and the one-off payments were of the same amount. The Societé Française was concerned with the lifestyles of those seeking its aid. It investigated those who were unknown to them, but most often the requests were presented by members or by another charitable organisation. The latter always received a favourable response, enjoying a form of guarantee in being made by people known to the organisation and whom the committee trusted. Moreover, the other charitable organisations were often involved in helping those they presented to the committee. The Ladies of Charity ${ }^{38}$ for example, appeared regularly in the committee's minutes, which sometimes recorded that they were delegated to follow-up on certain individuals. Thus, when the hospital asked the Societé to pay for a wooden leg for an elderly French widower, it agreed and pledged additional help, which the Ladies of Charity had to assess, but still did not consider financing the entire cost. ${ }^{39}$ This shows that its contribution was part of a programme of assistance, too costly to be assumed in its entirety. In the same way, the SFP granted its aid to individuals already helped and put forward by the Bureau central de bienfaisance (Central Charity Bureau), one of the private Genevan institutions which

37 Comité, 1886-1923. Société Française Philanthropique de Genève (Private Archives).

38 These were female philanthropists who worked with the Catholic Church in helping disadvantaged people.

39 Comité, Meeting of 13 Feb. 1894. Société Française Philanthropique de Genève (Private Archives). 
played a central role in matters of assistance. ${ }^{40}$ The latter notably agreed with other Genevan and foreign charities to divide up those seeking assistance on the basis of their nationality. The goal of this agreement was to rationalise assistance practices and avoid "duplication of efforts and abuses." 41 This document bears witness to the efforts of coordination and rationalisation amongst philanthropic bodies at this time. In general, the sources do not offer any examples of a situation where the SFP refused to contribute to helping a family when another charitable organisation was already involved.

Finally, while this group of French citizens, helped occasionally or regularly by the SFP, often appeared in the committee's minutes, they were not the principal cost factor, at least from 1901 on. Pensions always accounted for less than a third of charitable expenses (1907) and financial help was only a small part of that. These resources were allocated to 286 families in 1900 and 344 in 1901. The two other societies helped a smaller number of people: in 1910, the Euvre des Vieillards maintained on average 25 pensioners in a specially constructed shelter for French senior citizens. To these were added another 16 people receiving outdoor relief, and the Enfance Française abandonnée supported 72 children. ${ }^{42}$

The most important item was that of providing food relief (more than half of expenditures of this nature in 1907), which was distributed twice weekly in winter. Its beneficiaries formed the second group according to the type of aid that the SFP provided. To have access to it, they had to demonstrate that they were French nationals. The people who appeared there were not regularly quoted in the minutes of the committee, with the exception of a young girl who was followed up on because she had come looking for bread in 1890. We learn that "her father was a drunken widower" and that she spent her days "alone when her father was working or at the tavern with him." So, it was a matter of collaborating with the Ladies of Charity to place this child in the boarding school which her sister was already attending..$^{43}$ This example shows that the process of distributing charity also allowed philanthropists to observe claimants and to participate in the measures selected when they considered it appropriate. In this case, it was a matter of

40 See Flavio Baumann: La pauvreté apprivoisée ou l'assistance comme gestion de la détresse. Etude sur une société de bienfaisance genevoise à la fin du XIXe s. Le Bureau Central de Bienfaisance, 1867-1900 (Master's thesis, University of Geneva, 1983).

41 Accord amongst the Charitable Societies and Administrations (1880), quoted by Frank Lombard: Annuaire philanthropique genevois. Geneva 1903, 7.

42 Journal Français, 22 Apr. 1910.

43 Comité, meeting of 6 Feb. 1890. Société Française Philanthropique de Genève (Private Archives). 
removing the child from its "deplorable situation" 44 , in other words, of correcting what was considered a morally unacceptable way of raising a child. Charitable distribution was thus an instrument of social control, presenting an opportunity to gather and observe a marginalised part of the community and to focus on certain subjects. Furthermore, the distribution of essentials doubtless sprang from a form of collective responsibility on the part of the community, expressed by the French charitable organisations. The latter thus showed that they took care of vulnerable French citizens in Geneva. ${ }^{45}$

Finally, the third group of people in whom the SFP was interested in comprised those who received vouchers for the night shelter or soup kitchens or who were repatriated. In the SFP's archives, they were regularly designated "transients" (passagers), probably because they were not meant to stay in the city. At least part of them were probably transmigrants. They seemed to constitute the most problematic population for SFP's representatives. Indeed, in 1888, the treasurer explained that it was impossible for him to continue to receive people sent by the consulate and other philanthropic organisations in his home since "[...] many of these people, especially those transients who are generally not very interesting cheaters (rouleurs) [sic] turn up filthy, sometimes grey [drunk], one of them even followed by the police right up to the [treasurer's] door, which was far from agreeable." 46 The treasurer clearly distinguished between "transients" and others since the former, as the designation indicates, were not supposed to remain, while the others were established in Geneva, a distinction which the SFP contributed to maintaining through its activities.

This group of French migrants, not settled in Geneva, was sent by the SFP to the night shelter where they could sleep. Similar institutions existed in a number of European cities, notably in Paris, where they contributed to the maintenance of public order through the standards of hygiene and salubrity on their premises, and especially by offering an alternative to the street. ${ }^{47}$ The promoters of the Genevan night shelter were convinced that they were playing a socially important role in not refusing entry to their establishment (except in the case of inebriation). In 1904, they wrote: "Would it be wise to be very severe? We do not believe so; our city, which receives so many refugees from surrounding countries,

44 Ibid.

45 The notion of collective responsibility in this context is developed by Nancy Green with respect to the Jewish community of Paris, see Green, Give and Receive, 197-226.

46 Comité, Meeting of 19 Oct. 1888. Société Française Philanthropique de Genève (Private Archives).

47 For Paris, see Lucia Katz: Habiter dans les asiles de nuit parisiens. Le cas de l'GEuvre de l'Hospitalité de Nuit à la fin du XIXe siècle, in: Hypothèses 6 (2013), 59-71. 
is still one of the safest; if no one begs in the streets and if nighttime attacks are practically unheard of, we firmly believe we can take credit for that." 48

The night shelters' role was to serve as transit points or transitional housing, since they limited access to a certain number of nights (seven in Geneva, three or four in Paris). Foreigners could sleep there before leaving Geneva. They also served as an alternative to their planned imprisonment, intended as a measure to work against "vagrants". In Geneva, between 1876 and 1903, foreigners constituted between 40 and 50 per cent of the population sleeping in the night shelter; 16 to 23 per cent were French. ${ }^{49}$

Vouchers, provided mostly by the police, with a small number provided by the SFP, gave access to the shelter. The importance of the police in a charitable endeavour, one of the goals of which was to contribute to the maintenance of public order, shows that the individuals concerned were highly marginalised. The shelter presented itself as a temporary place of respite, which would allow the authorities to avoid having to lock up the nationals and instead enable them to find a better situation, permitting the foreigners to rest a few nights before continuing their journey. The commitment of the police was part of their work in maintaining public order. ${ }^{50}$ The collaboration of philanthropic institutions shows that they were active participants in this program. Philanthropic institutions therefore played an important role by allowing people to stay off the streets. However, by not helping everyone, they established limits: they assisted in the removal of some foreigners by contributing financially to their repatriation and by leaving them in the hands of the police. The latter identified them in the public arena and served them with an expulsion order signed by the canton's minister of justice who "demanded" that these individuals "withdraw from the canton immediately". ${ }^{51}$

48 XXVIIIth Report of the Committee, Asile de nuit. Geneva 1904, esp. 6.

49 XXVIth, XXVIIth, XXVIIIth Reports of the Committee, Asile de nuit. Geneva 1901-1904.

50 The Genevan penal code offers the following definition: "Vagrants are those with no fixed abode, and no means of support, and who do not regularly practice a trade or a profession." It also provides for a penalty varying between a day and a month for "anyone found begging" (Penal code of the Canton of Geneva, 21 Oct. 1874, Section V, Articles 242 and 243).

51 See the expulsion orders conserved in the series 1985 va 22 Étrangers J, Department of Justice and Police (Archives d'État de Genève, Geneva, Switzerland). 


\section{Those Expelled from the Canton}

At the turn of the century, administrative expulsions from the canton of Geneva increased substantially.52 In 1902, the Department of Justice and Police issued 1,121 expulsion orders against individuals and their families. ${ }^{53}$ In that year, Geneva experienced a general strike, which was the occasion for renewed police activity against foreigners suspected of involvement in "anarchist" activities or of belonging to groups with such tendencies. The Department of Justice and Police expelled by order or sometimes as a simple "public security measure" 78 persons, of whom 50 were Italians and 20 French, ${ }^{54}$ that is barely seven per cent of those expelled in 1902. The general strike had only a limited impact on the number of expulsions, since in 1902 there were fewer expulsions than in 1901 and in 1903. The strikes, which multiplied during the period from 1888 to 1914, were thus not the principal reason for the increased number of expulsions at the turn of the century. Instead, the explanation lies in the work of the police, to which the law granted relative autonomy in managing the canton's foreign population. The minister responsible for the Department of Justice and Police, with the authority delegated by the Genevan government, had the power to expel with an administrative measure and hence, without going through a judicial process - any foreigner whose "conduct was bad", who was not "in a condition to provide for his own maintenance or that of his family" or "whose stay could harm the interests of the country or the security of the state". ${ }^{55}$ The range of behaviours which could fall under this law was extremely vast, thus making expulsion arbitrary.

It is interesting to note that the months with the most expulsions were November, December and January, when there was the least activity in the sectors of agriculture and construction. One might wonder whether the expulsions were not a manner of handling the labour market, by expelling those who failed to find work.

52 The figures available in the Rapports administratifs du Conseil d'État (1888-1914) were compiled by Anne Varidel: Les étrangers à Genève de 1888 à 1914 (Master’s thesis, University of Geneva, 1988), 109.

53 Series 1985 va 22, Étrangers J, boxes 187-196, Department of Justice and Police.

54 On the general strike of 1902, see Charles Philipona: Le Courrier de Genève et la grève générale de 1902, in: Jean Batou, Mauro Cerutti and Charles Heimberg (eds.): Pour une histoire des gens sans Histoire. Ouvriers, exclues et rebelles en Suisse 19e-20e siècles. Lausanne 1995, 233-244. On the surveillance work of the political police of Geneva, see Ignace Cuttat: Les plus basses \& les plus louches actions contre la liberté du citoyen? Organisation et méthodes de la police politique à Genève, 1889-1914. (Master's thesis, University of Geneva, 2013).

55 Recueil des lois et actes du gouvernement. Loi sur la police des étrangers du 9 février 1844, art. 27 and 28. Geneva 1844, 69-70. 


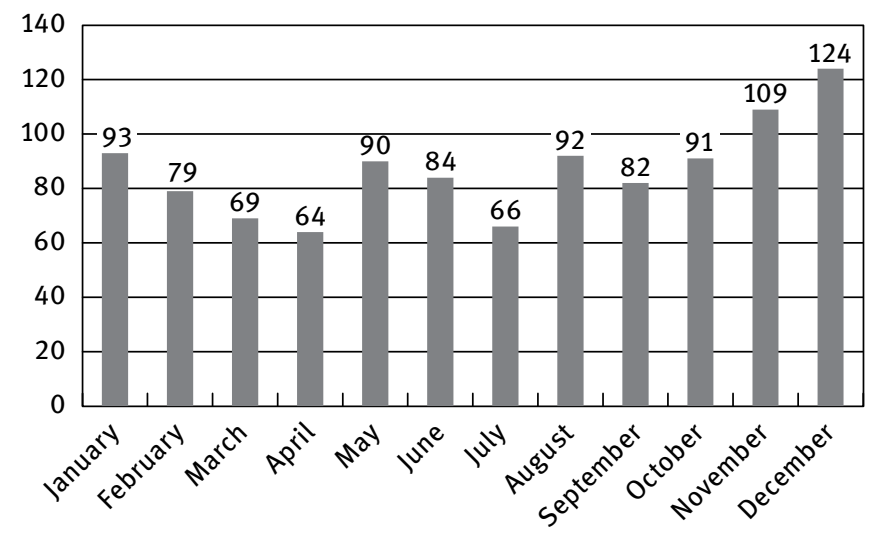

Graph 1: Seasonal Evolution of Expulsions in 1902 (without those expelled due to the strike, therefore "-78 individuals" in the month of October).

Table 3: Individuals Expelled in 1902 by Nationality ${ }^{56}$

\begin{tabular}{lccr}
\hline Nationality & $\begin{array}{l}\text { Individuals expelled } \\
\text { in connection } \\
\text { with the strike }\end{array}$ & $\begin{array}{l}\text { Individuals expelled } \\
\text { (total) }\end{array}$ & ${\text { In } \%^{\mathbf{5}^{7}}}$ \\
\hline Switzerland (outside of Geneva) & 0 & 90 & 8.0 \\
German States & 6 & 110 & 9.8 \\
France & 20 & 550 & 49.1 \\
Italy & 50 & 307 & 27.4 \\
Other & 2 & 64 & 5.7 \\
\hline Total & 78 & 1121 & 100.0 \\
\hline
\end{tabular}

In terms of social profile, the typical French national expelled from Geneva was a relatively young unmarried man whom the Genevan police declared to be "without proper documentation, with no fixed address and with no means of support." ${ }^{8}$ Indeed, out of 550 expulsions, 468 concerned single men, 60 single women and only 18 families; more than three quarters of the files related to unmarried people (77.1 per cent). ${ }^{59}$ Women constituted barely 11 per cent of this

56 Series 1985 va 22, Étrangers J, boxes 187-196.

57 The people expelled in connection with the strike are included in this calculation.

58 See files in series 1985 va 22, Étrangers J, boxes 187-196.

59424 single people, four divorced, 79 married, twelve widowed and 14 for whom the information is missing. 
population, a fairly astounding finding since they were more numerous than men amongst foreigners living in the canton. ${ }^{60}$ This may be explained by the fact that the majority of female foreigners arriving in Geneva were employed as servants, ${ }^{61}$ a sector of activity where there was always high demand. ${ }^{62}$

Half of those expelled were born after 1876; they were less than 26 years old in 1902. Those under 30 constituted more than 66 per cent of the total. Most came to the canton shortly before their expulsions, often on the same day. Rarely do those who had been there for a long time appear amongst the expelled, even if some indicated residence in Geneva "since birth." In most cases, the expulsion order was based on a combination of factors. "Vagrancy" appeared in 255 files out of 550, the explanation "with no visible means of support" in 266, and the absence of a fixed residence in $435 .{ }^{63}$ Social and economic vulnerability was, therefore, clearly an important factor in the practice of expulsion. Thus, the work of the police consisted of clearing the public space of foreigners deemed undesirable, due to their itinerant and unstable lifestyle. This process stemmed both from a set of attitudes which proscribed "vagrants" 64 and their lifestyle, and from measures aiming to maintain security and public order vis-⿳亠丷⿵冂-vis those considered a threat. ${ }^{65}$

Most of those expelled came from neighbouring French departments. The Haute-Savoie came first with 107 expelled. The departments near Geneva (Doubs 11, Jura 10, Ain 26, Rhône 53, Isère 22, Savoie 11, and Saône-et-Loire 16) totaled another 149 expelled, with Haute-Savoie accounting for almost 47 per cent of this population. Yet some came from farther afield, such as the 34 Parisians in the group. Most of these people claimed to be active in the secondary and tertiary sectors or in agriculture: we do not find representatives of the liberal professions. The most commonly named occupations declared by those who were expelled were those of farmer (34), day laborer (31), unskilled worker (32), mechanic (18)

60 Varidel, Les étrangers à Genève, 44.

61 According to Morisseau, 58.5 per cent of female arrivals who requested a residence permit in 1901 were employed in this sector. Morisseau, Les immigrés, 19. Moreover, in 1910, foreigners constituted 50.3 per cent of the servants in Geneva. Varidel, Les étrangers à Genève, 77-78.

62 Anne-Lise Head-König: Les apports d'une immigration féminine traditionnelle à la croissance des villes de la Suisse. Le personnel de maison féminin (XVIIIe-début du XXe siècle), in: Revue Suisse d'Histoire 49 (1999), 47-63, esp. 52-53.

63 "Theft" appeared in 63 files, "fraud" in 16, and "assault and battery" in 23.

64 On the social image of the vagrant, see Dominique Kalifa: Les bas-fonds. Histoire d'un imaginaire. Paris 2013.

65 Vagrants, objects of suspicion because unknown and from elsewhere, were associated with laziness, idleness, and a kind of industry of begging and crime. See the analysis for France by André Gueslin: D'ailleurs et de nulle part. Mendiants vagrants, clochards, SDF en France depuis le Moyen Âge. Paris 2013, 201-228. 
and servant (twelve, of whom ten were women). ${ }^{66}$ Our results correspond to those of a study on the same population between 1905 and $1911 .{ }^{67}$

The hypothesis of expulsion sanctioning social failure, ${ }^{68}$ which affected the individuals who came seeking employment and, finding none, were left without means, seems wholly convincing in the light of these data. For the authorities dealing with a young population, newly arrived in the canton, expulsion was a means to prevent these individuals from living on the streets while they waited for work. The French charitable organisations only marginally concerned themselves with these persons. These were probably the ones designated "transients" in the organisations' archives and who constituted, as we have seen, a problematic population in the view of French philanthropists. Once the police encountered them, they were immediately expelled from the canton by an administrative measure.

This practice, part of the tendency of the time to prevent people from living on the street, was reflected in laws concerning the police and the measures taken against "vagrancy" and "begging". The experiences of those expelled are, in this regard, very revealing. François B., aged 29 and originally from a small village on the shores of lac d'Annecy (Haute-Savoie), came to try his luck in Geneva in March 1902. He had recently completed his apprenticeship as a cook for the Christian Brothers in Annecy, after having finished his military service with the mountain infantry. He seemed, therefore, in good health and well-trained. Yet when the police arrested him for creating a "scandal" in the street, they discovered that he had no "means of support" and served him with an expulsion order. ${ }^{69}$ In many cases, expulsion reflected the work of the police, who controlled the situation of people found in the street and, with an expulsion order, sanctioned those who declared that they had no "means" or who were treated as "vagrants". Thus, the police could expel more than ten people a day. In this way, they played the role of a filtering body to avoid allowing foreigners with no employment or income to remain on the streets of the canton. This also permitted them to remove the most vulnerable, in accordance with the key concerns of Genevan philanthropists who feared that the foreigners would swell the ranks of those asking for help. ${ }^{70}$ Consequently, a number of aspects of police activity coincided with the preoccupations of philanthropists: their work allowed them to expel people likely to ask for help from

66 Series 1985 va 22, Étrangers J, boxes 187-196.

67 Pierre Bungener: Les indésirables à Genève 1905-1911. Mémoire exemplaire basé sur l'étude des files d'expulsions administratives du Département de Justice et Police genevois (Master's thesis, University of Geneva, 1990).

68 Rosental, Migrations, 335-373.

69 Series 1985 va 22, Étrangers J, file 234, box 188.

70 Bureau central de bienfaisance. XXIXe Rapport annuel. Geneva 1896, 12. 
the canton, it encouraged their departure in assisting repatriation and it contributed to charitable organisations such as the night shelter by offering vouchers to users. Their action was also in line with that of French philanthropists who, in the minutes of their committee meetings, regularly referred to the services the police performed for them..$^{71}$ The police were always mentioned in the context of collaboration and never because they had come into conflict with the philanthropists.

Nonetheless, the police were no less severe in their treatment of people long established in Geneva whose conduct "gave rise to complaints." Another François B., aged 23, born and raised by his French parents in Geneva, was questioned by the police because he "frequented public gardens in the company of shifty individuals, must be one of them and never works". ${ }^{72}$ The reasons cited for his expulsion order related to his conduct and the irregularity of his residence permit, but it was certainly because the police suspected him of behaving in a morally objectionable manner and of being idle that they inspected him and finally expelled him from the canton, although his parents remained there.

Factors related to morality were cited even more emphatically in the cases of women. When the expulsion order mentioned that a woman "gives rise to complaints", this often meant, that the woman was suspected of selling herself outside of brothels or that she was indeed discovered "soliciting" in public space. In general, the reasons recorded for expulsion orders against women differed from those of their male counterparts. For men, we most often find "vagrancy" (246/468), and "no visible means of support" (261/468), while for women, these were only mentioned in 7/60 and 12/60 files respectively. The dominant reason for women's expulsion orders was that their conduct "gave rise to complaints" (34/60), while this was much less common for men (104/468). Moreover, for a man, this reason also referred to political activities; in particular, it was invoked in expulsion orders related to the strike. Even in the declared motivations, expulsion seemed largely arbitrary, a fact denounced by political representatives at the turn of the twentieth century. ${ }^{73}$ They seemed to be a flexible instrument for the police in their mission to maintain public order.

\footnotetext{
71 See Comité, 1886-1914. Société Française Philanthropique de Genève (Private Archives).

72 Series 1985 va 22, Étrangers J, file 467, box 190.

73 See Varidel, Les étrangers à Genève, 111-112.
} 


\section{Conclusions}

The position of the migrant in the majority society was largely determined by his place in the social hierarchy. The most affluent members of the colony could meet to cultivate their specific national traits and to celebrate their patriotic holidays. They were well integrated into the majority society and, through their charitable organisations, collaborated with Genevan philanthropists and with the police. They put themselves forward as representatives of their community and took responsibility for helping the most disadvantaged. At the other extreme of the social hierarchy, vulnerable foreigners could either be helped by French and/or local charitable organisations and the police, or be ordered to be expelled from the canton. The management of migrants was the result of the combination of efforts of these local and French charitable organisations and the work of the police. The affluent French who represented the colony collaborated with this policy, while their compatriots who were completely destitute were subjected to this practice and had to leave the canton.

This distinction can be found in the very construction of the "problem". The discourse establishing the foreigners as a "problem" or a "danger" for Geneva did not choose productive or affluent individuals, such as members of the French organisations analysed earlier, as targets, but those who risked becoming "vagrants" or "beggars". ${ }^{74}$ The distinction between the foreigners considered desirable and those labeled undesirable reflected the economic and social developments of this period. On the one hand, industry, agriculture and even Genevan homes needed this foreign manpower, which was indispensable to the canton's economic development. Industrialists and merchants involved in French philanthropic societies, the Cercle and the French Chamber of Commerce in Geneva, who were part of the economic engine, showed themselves to be solidly integrated into the local fabric, even if they were meeting to cultivate a particular link with their homeland. Yet on the other hand, social changes entailed their share of inequalities, which were seen in the public space in the form of people who had fallen into great insecurity. Public and private institutions offering social protection gave themselves the mission of rescuing them through assistance, combined with re-

74 This situation would change during the First World War. In 1918, the Swiss government promoted a law against economic "Überfremdung" ("overforeignisation", the feeling of being swamped by foreigners) in order to preserve the national character of Swiss companies. The ordinance promoted by the Swiss government provided that the majority of firm's board members should have the Swiss nationality. See Thomas David et al.: De la "Forteresse des Alpes" à la valeur actionnariale. Histoire de la gouvernance d'entreprise suisse (1880-2010). Zurich 2015, esp. 59-60. 
covery measures, such as the night shelter. They considered aid to their fellow citizens legitimate, but refused to extend this right to foreigners. Some of the latter, fitting specific social profiles, were supported by a combination of French and Genevan philanthropic societies' efforts, which allowed them to maintain a roof over their heads and to remain invisible in the street. It was actual visibility in the public space which posed a problem.

Moreover, the management of the French national group by various bodies, the police, and the Genevan and French charitable organisations, demonstrates how the urgent questions of the time, the right to assistance and the nationalisation of Swiss society, were intertwined. ${ }^{75}$ Indeed, the Confederates, a term which designates the non-Genevan Swiss, who in 1900 constituted 25.9 per cent of the population, were the largest group to use the night shelter between 1876 and 1903, with rates oscillating around 35-36 per cent from 1901 on. They also comprised a third of new families assisted by the Central Charity Bureau in 1902, far ahead of the Genevans and the French who each constituted approximately a quarter of this population. ${ }^{76}$ Nonetheless, even if the Confederates appeared to be the most significant beneficiaries of these two charitable organisations, they were not discussed in terms of the danger they might represent for the "Genevan nationality", to return to the terms used by the statistician Emmanuel Kuhne. In fact, they did not constitute a threat to the public funds since, in principle, their municipality of origin had to provide for their maintenance. The contrasting treatment of the Confederate and foreign populations is a revealing reflection of a paradigm shift: it was no longer a matter of distinguishing Genevans from non-Genevans, but rather of differentiating between Swiss (Genevans and Confederates) and others. The dividing line was determined very clearly by the right to assistance and the financial questions which flowed from this. ${ }^{77}$

75 Arlettaz and Arlettaz, L'État social national, 191-217.

76 Bureau central de bienfaisance. XXXVI ${ }^{\mathrm{e}}$ Rapport annuel. Geneva 1902, 11-12.

77 Brigitte Studer, Gérald Arlettaz and Regula Argast: Le droit d'être suisse. Acquisition, perte et retrait de la nationalité de 1848 à nos jours. Lausanne 2013. 